\title{
CENTILE CHART FOR ANTHROPOMETRIC MEASUREMENTS OF NEWBORNS
}

\author{
Thekkumpat Subramanian Athira1, Vellithiruthy Thazhath Ranjith ${ }^{2}$
}

${ }^{1}$ Assistant Professor, Department of Paediatrics, Amala Institute of Medical Sciences, Thrissur, Kerala, India. ${ }^{2}$ Associate Professor, Department of ENT, Government Medical College, Thrissur, Kerala, India.

\author{
BACKGROUND \\ ABSTRACT \\ Anthropometric measurements in newborns including height, weight and head circumference are frequently used for evaluation of \\ prenatal growth and nutritional status of the baby. \\ This study was conducted in a tertiary care centre in Kerala, India to derive local population specific centile charts.
}

\section{MATERIALS AND METHODS}

It was a descriptive study. 1000 live born full-term neonates were included in the study. The crown-heel length and head circumference were measured within 48 hours after birth. The mean values, standard deviation and centiles were calculated. Gender specific centile charts were constructed.

\section{RESULTS}

The mean crown-heel length for male babies was $48.869 \mathrm{~cm}$ with a standard deviation of 2.381 . The mean crown-heel length for female babies was $48.849 \mathrm{~cm}$ with a standard deviation of 2.365 . The mean head circumference for male babies was $34.213 \mathrm{~cm}$ with a standard deviation of 1.664. The mean head circumference for female babies was $34.123 \mathrm{~cm}$ with a standard deviation of 1.703.

\section{CONCLUSION}

The mean crown-heel length and head circumference in the present study were similar to the studies conducted in both developing and developed countries.

\section{KEY WORDS}

Anthropometry, Centile Chart, Crown-Heel Length, Head Circumference.

HOW TO CITE THIS ARTICLE: Athira TS, Ranjith VT. Centile chart for anthropometric measurements of newborns. J. Evolution Med. Dent. Sci. 2018;7(37):4077-4079, DOI: 10.14260/jemds/2018/911

\section{BACKGROUND}

Anthropometric measurements in newborns are frequently used for evaluation of prenatal growth and nutritional status of the baby. They are important predictors of short-term and long-term mortality and morbidity. Babies whose birth weights are low are at higher risk of neonatal complications like hypoglycaemia, hypothermia and asphyxia.[1],[2],[3] Body length is also of prognostic significance. An infant who is underweight, but with normal length has normal growth potential, whereas a short and small baby may have impaired growth potential. The decreased length may be because of genetic, infectious or teratogenic insults in early foetal life.[4],[5] Body length is an independent predictor of perinatal mortality with long infants being at higher risk of perinatal deaths.[6] Infants born with excessively small or large heads may have malformations of central nervous system due to genetic, chromosomal or teratogenic insults that may carry grave prognostic implications.

Lubchenco and his colleagues published gestational age specific centile charts in 1963.[7] This gained wide acceptance and such charts were recommended for evaluating the nutritional status of newborns and also for checking the

'Financial or Other Competing Interest': None.

Submission 22-08-2018, Peer Review 03-09-2018,

Acceptance 05-09-2018, Published 10-09-2018.

Corresponding Author:

Dr. Thekkumpat Subramanian Athira,

Deepakam, Green Gardens,

P. O. Chittilappally, Thrissur District, Kerala, India.

E-mail: athirathekkumpat@yahoo.co.in

DOI: $10.14260 /$ jemds $/ 2018 / 911$ postnatal growth of preterm infants. Though many centile charts are available for neonatal anthropometric parameters, it is always preferable to have local standards derived from the same population. There is also growing preference for gender specific charts, as many studies show that female babies are at lower risk of mortality and morbidity than males despite their smaller size at the same gestational age. In this study, we measured the crown-heel length and head circumference of term newborns for creating gender specific centile charts for newborns born at Government Medical College, Kottayam, Kerala.

\section{MATERIALS AND METHODS}

The study was conducted at Government Medical College, Kottayam, from January 2005 to January 2006 on 1000 term live-born babies. It was a descriptive study. Babies were included in the study irrespective of any maternal complications and the mode of delivery, as the aim was to create a centile chart representative of community at large. Babies were considered full-term if the gestational age was 37 completed weeks. If the gestational age was not known or unreliable, then antenatal USG done before 20 weeks of gestation was taken into consideration. Babies who were in a moribund condition and babies with indeterminable gestational age were excluded.

The Crown-Heel Length (CHL) and Head Circumference (HC) were measured within 48 hours after birth. The CHL was measured with an infantometer to the nearest $0.1 \mathrm{~cm}$. Head circumference was measured using a non-elastic tape to the nearest $0.1 \mathrm{~cm}$. 


\section{Statistical Analysis}

The data obtained was analysed and mean values, standard deviation and various centiles were calculated separately for males and females. The difference between males and females was studied using independent student's t-test. Gender specific centile charts were constructed. SPSS version 21.0.

\section{RESULTS}

1000 full-term babies were studied. The male-to-female ratio was 1000: 1070 with 484 males and 516 females. The mean crown-heel length for males was $48.869 \mathrm{~cm}$ with a standard deviation of 2.381. The minimum CHL measured for males was $36 \mathrm{~cm}$ and maximum was $52 \mathrm{~cm}$. The median CHL was $49.5 \mathrm{~cm}$ and mode was $50 \mathrm{~cm}$. The mean crown-heel length for females was $48.849 \mathrm{~cm}$ with a standard deviation of 2.365. The minimum CHL measured for females was $39.8 \mathrm{~cm}$ and maximum was $52 \mathrm{~cm}$. The median CHL was $49.5 \mathrm{~cm}$ and mode was $50 \mathrm{~cm}$. The difference between male and female values was analysed using independent student's t-test. The difference was not statistically significant ( $p$ value $=0.894$ ).

The mean head circumference for males was $34.213 \mathrm{~cm}$ with a standard deviation of 1.664. The minimum HC measured for males was $25 \mathrm{~cm}$ and maximum was $36.2 \mathrm{~cm}$. The median HC was $34.8 \mathrm{~cm}$ and mode was $35 \mathrm{~cm}$. The mean head circumference for females was $34.123 \mathrm{~cm}$ with a standard deviation of 1.703. The minimum HC measured for females was $27 \mathrm{~cm}$ and maximum was $36.8 \mathrm{~cm}$. The median $\mathrm{HC}$ was $34.6 \mathrm{~cm}$ and mode was $35 \mathrm{~cm}$. The difference between male and female values was analysed using independent student's t-test. The difference was not statistically significant ( $p$-value $=0.398$ ).

\begin{tabular}{|c|c|c|c|c|}
\hline & Male & Female & T value & P value \\
\cline { 1 - 3 } Mean & 48.869 & 48.849 & \multirow{2}{*}{0.113} & \multirow{2}{*}{0.894} \\
\cline { 1 - 3 } SD & 2.381 & 2.365 & & \\
\hline \multicolumn{5}{|c|}{ Table 1. Crown-Heel Length } \\
\hline
\end{tabular}

\begin{tabular}{|c|c|c|c|c|}
\hline & Male & Female & T value & P value \\
\cline { 1 - 3 } Mean & 34.213 & 34.123 & \multirow{2}{*}{0.844} & \multirow{2}{*}{0.398} \\
\cline { 1 - 3 } SD & 1.664 & 1.703 & & \\
\hline \multicolumn{5}{|c|}{ Table 2. Head Circumference } \\
\hline
\end{tabular}

The $3^{\text {rd }}, 5^{\text {th }}, 10^{\text {th }}, 25^{\text {th }}, 50^{\text {th }}, 7^{\text {th }}, 90^{\text {th }}, 95^{\text {th }}$ and $97^{\text {th }}$ centiles were calculated for CHL and HC.

\begin{tabular}{|c|c|c|c|}
\hline Centile & Total & Male & Female \\
\hline $3^{\text {rd }}$ & 41 & 41 & 41 \\
\hline $5^{\text {th }}$ & 42.9 & 43 & 42 \\
\hline $10^{\text {th }}$ & 46 & 46.2 & 46 \\
\hline $25^{\text {th }}$ & 48.2 & 48 & 48.5 \\
\hline $50^{\text {th }}$ & 49.5 & 49.5 & 49.5 \\
\hline $7^{\text {th }}$ & 50 & 50 & 50 \\
\hline $90^{\text {th }}$ & 50.8 & 51 & 51 \\
\hline $9^{\text {th }}$ & 51 & 51.2 & 51.4 \\
\hline $9^{\text {th }}$ & 51.2 & 51.5 & 51.8 \\
\hline \multicolumn{4}{|c|}{ Table 3. Centile Chart for CHL (cm) } \\
\hline
\end{tabular}

The length of 169 babies were less than $48 \mathrm{~cm}$, while none had length more than $52 \mathrm{~cm}$.

\begin{tabular}{|c|c|c|c|}
\hline Centile & Total & Male & Female \\
\hline $3^{\text {rd }}$ & 29.5 & 29.5 & 29 \\
\hline $5^{\text {th }}$ & 30.5 & 30.8 & 30 \\
\hline $10^{\text {th }}$ & 32 & 32 & 32 \\
\hline $25^{\text {th }}$ & 33.5 & 33.6 & 33.5 \\
\hline $50^{\text {th }}$ & 34.8 & 34.8 & 34.6 \\
\hline $7^{\text {th }}$ & 35.1 & 35 & 35.1 \\
\hline $9^{\text {th }}$ & 36 & 35.8 & 36 \\
\hline $9^{\text {th }}$ & 36.1 & 36 & 36.1 \\
\hline $9^{\text {th }}$ & 36.2 & 36.2 & 36.5 \\
\hline \multicolumn{4}{|c}{ Table 4. Centile Chart for HC (cm) } \\
\hline
\end{tabular}

\begin{tabular}{|c|c|c|c|c|c|}
\hline Study & $\mathbf{1 0}^{\text {th }}$ & $\mathbf{2 5}^{\text {th }}$ & $\mathbf{5 0}^{\text {th }}$ & $\mathbf{7 5}^{\text {th }}$ & $\mathbf{9 0}^{\text {th }}$ \\
\hline Lubchenco & 45.6 & 47.9 & 49 & 50.2 & 52.3 \\
\hline China & 47.5 & 49 & 50.5 & 51.5 & 52.5 \\
\hline Present & 46 & 48.2 & 49.5 & 50 & 50.8 \\
\hline
\end{tabular}

\begin{tabular}{|c|c|c|c|c|c|}
\hline Study & $\mathbf{1 0}^{\text {th }}$ & $\mathbf{2 5}^{\text {th }}$ & $\mathbf{5 0}^{\text {th }}$ & $\mathbf{7 5}^{\text {th }}$ & $\mathbf{9 0}^{\text {th }}$ \\
\hline Lubchenco & 31.7 & 33 & 34 & 35 & 35.85 \\
\hline Chinese & 32.9 & 33.2 & 34 & 35 & 35.5 \\
\hline Present & 32 & 33.5 & 34.8 & 35.1 & 36 \\
\hline
\end{tabular}

There are a few limitations for this study. Gestational age determination was not based on antenatal USG in all babies, which would have been more accurate. All babies more than 37 weeks of gestation were taken as term. Preterm babies were not included in the study. A bigger study to construct gestational age specific centile charts is needed.

\section{DISCUSSION}

This study was conducted in a tertiary care centre which caters to people of all socioeconomic strata, but majority being lower middle class. It also covers three districts of the state of Kerala, India. The study was hence done in a representative population with adequate number of study subjects. Many studies done in developing countries like Nepal[8] and Bangladesh ${ }^{[9]}$ show lower mean birth weight and weight centiles when compared to values from developed countries like Canada,[10] England[11] and China.[12] Even in these studies, the length and head circumference did not show much difference between the developed and developing countries. In the present study also we found that the mean crown-heel length and head circumference were comparable with the results from both developed and developing countries. A study conducted in Nigeria[13] showed mean HC of $34.2 \mathrm{~cm}$, while that from England[11] showed mean $\mathrm{HC}$ of $35.25 \mathrm{~cm}$, which are similar to the values obtained in the present study. The mean CHL in a study from Zambia[14] was $48.57 \mathrm{~cm}$, while study from China showed a value of $50.2 \mathrm{~cm}$. Both did not show much difference from the present study. The centile values for both the measurements were also comparable to various studies.

\section{CONCLUSION}

The mean crown-heel length and head circumference in the present study are similar to the values from studies conducted in both developing and developed countries. The lower mean and centile values seen in birth weight measurements when compared to developed countries is not seen with CHL and HC measurements. Even then it is always better to have local population specific centile charts to avoid false labelling of babies to high-risk group. 


\section{REFERENCES}

[1] Wilcox AJ, Skjaerven R. Birth weight and perinatal mortality: the effect of gestational age. Am J Public Health 1992;82(3):378-82.

[2] Susser M, Marolla FA, Fleiss J. Birth weight, fetal age and perinatal mortality. Am J Epidemiology 1972;96(3):197-204.

[3] Williams RL, Creasy RK, Cunningham GC, et al. Fetal growth and perinatal viability in California. Obstet Gynaecol 1982;59(5):624-32.

[4] Allen MC. Developmental outcome and follow up of the small for gestational age infants. Semin Perinatol 1984;8(2):123-56.

[5] Commey JO, Fitzhardinge PM. Handicap in the preterm small for gestational age infant. J Pediatr 1979;94(5):779-86.

[6] Melve KK, Gjessing HK, Skjaerven R, et al. Infants' length at birth: an independent effect on perinatal mortality. Acta Obstet Gynecol Scand 2000;79(6):45964.

[7] Lubchenco LO, Hansman C, Dressler M, et al. Intrauterine growth as estimated from live born birth weight data at 24 to 42 weeks of gestation. Pediatrics 1963;32(5):793-800.
[8] Christian P, Khatry SK, Katz J, et al. Effects of alternative maternal micronutrient supplements on low birth weight in rural Nepal: double blind randomized community trial. BMJ 2003;326(7389):571.

[9] Haque F, Hussain AM. Detection of low birth-weight new born babies by anthropometric measurements in Bangladesh. Indian Journal of Paediatrics 1991;58(2):223-31.

[10] Kramer MS, Platt RW, Wen SW, et al. A new and improved population-based Canadian reference for birth weight for gestational age. Pediatrics 2001;108(2):E35.

[11] Ounsted M, Moar VA, Scott A. Head circumference chart updated. Arch Dis Child 1985;60:936-9.

[12] Fok TF, So HK, Wong E, et al. Updated gestational age specific birth weight, crown-heel length and head circumference of Chinese newborns. Arch Dis Child Fetal Neonatal Ed 2003;88(3):F229-F36.

[13] Eregie CO. Arm and head measurements in the newborn. East Afr Med J 1993;70:46-7.

[14] Bhat GJ, Mukelbai K, Shastri GN, et al. Anthropometric parameters of Zambian infants at birth. J Trop Pediatr 1989;35(3):100-4. 